\title{
Appendectomy Realized with Local Anesthesia: A Case Report
}

Moran-Sierra Oscar ${ }^{1 *}$, Trujillo-Bracamontes Francisco' ${ }^{1}$, Quintero-García Benjamin'1, Ríos-Beltrán Jose', Garrido-Rojo Miguel', Niebla-Torres Mariela', Martinez-Garcia Javier $\mathrm{J}^{3,4}$, Canizalez-Roman Adrian ${ }^{3,5}$, Murillo-Llanes Joel ${ }^{5}$ and Lopez-Huitron Melissa ${ }^{6}$

${ }^{1}$ Department of Surgery, Regional Hospital ISSSTE, México

${ }^{2}$ Department of Surgery, Pediatric Hospital of Sinaloa, Mexico

${ }^{3}$ School of Medicine, Autonomous University of Sinaloa, Mexico

${ }^{4}$ Emergency Room Service, Pediatric Hospital of Sinaloa, Mexico

${ }^{5}$ Departmet of Research, The Women's Hospital, Secretariat of Health, Mexico

${ }^{6}$ Emergency Room Service, Regional Hospital, ISSSTE, México

\begin{abstract}
Background: The first known appendectomy was performed in 1736 by Claudius Amyand in London. In 1889, Charles McBurney published his Landmark paper in the New York State Medical journal describing the indications for early laparotomy for the treatment of appendicitis. Eventually, early appendectomy became the accepted standard of care.
\end{abstract}

Methods: We present the case of an 8-year-old male patient treated for acute appendicitis. We performed an appendectomy under local anesthesia and anxiety management through sedation.

Results: The procedures performed have been used with good results, offering the advantages in addition to producing less postoperative pain. This technique has the lowest impact respiratory and clinical benefits.

Conclusion: The appendectomy under local anesthesia and sedation is a promising technique and it can be considered an alternative in high risk patients and low resource settings.

Keywords: Appendicitis; Appendectomy; Local anesthesia; Fentanyl; Dexmetomidina; Propofol; Ilioinguinal; Iliohypogastric nerves

\section{Introduction}

The first known appendectomy was performed in 1736 by Claudius Amyand in London [1]. He operated on an 11-year old boy with a scrotal hernia and a fecal fistula. Within the hernia sac, Amyand found a perforated appendix surrounded by omentum. The appendix and omentum were amputated [1]. It would be over a century later before appendicitis was widely recognized as a common cause of a right lower quadrant pain. In 1886, Reginald Fitz presented his findings regarding appendicitis and recommended consideration for operative treatment [2]. In 1889, Charles McBurney published his Landmark paper in the New York State Medical journal describing the indications for early laparotomy for the treatment of appendititis [3]. He notified in 1884 the incision that bears his name [3]. Eventually, early appendectomy became the accepted standard of care, with broad indications in order to prevent perforation. However, this had almost no impact on the incidence of perforated appendicitis or on the mortality of appendicitis [4].

Despite the great progress over time to treat appendicitis, no one had attempted an appendectomy under local anesthesia, despite being less invasive, less morbility and less costly than general anesthesia. We report the case of an appendectomy performed under local anesthesia and anxiety management through sedation in the "Pediatric Hospital of Sinaloa".

\section{Clinical Case}

8-year-old male patient originally from Cosala, Sinaloa, Mexico, healthy, that goes to the emergency department because of abdominal pain of two days of evolution of Sudden onset periumbilical and diffuse pain, progressive, accompanied by nausea and vomiting that eventually localizes to the right lower quadrant, was treated with analgesics by his mother dulling pain momentarily, mothers refers that pain increased as well as vomiting so she decided to take him to the emergency room. In the physical exploration: patient looked in accordance to his age, sweating, pulse rate increased, dehydrated oral mucosa, thorax normal, the abdomen was distended, decreased peristalsis, hard, barely depressible, tenderness near McBurney's point, muscular guarding in the right iliac fossa, positive rebound tenderness, presenting results as alteration leukocytosis $>21,000$ cells $/ \mathrm{mm}^{3}$ accompanied by a polymorphonuclear prominence. It was decided to have an emergency surgery for acute appendicitis prior informed consent, using sedation with fentanyl at dosis of $2 \mathrm{mcg} / \mathrm{kg}$, dexmetomidina $1 \mathrm{mcg} / \mathrm{kg}$, propofol $100 \mathrm{mcg} / \mathrm{kg}$ these are using to avoid the anxiety of the patient as well as for the management of visceral pain, it was decided to manage the somatic pain with local anesthesia with simple lidocaine $2 \%$ infiltrate deeply between the eleventh rib and anterior superior iliac spine (Figure 1). Later on the incision line (two centimeters inside and two centimeters below the anterior superior iliac spine), for some authors this technique is insufficient, so it is complemented by local infiltration on the skin to be incised (Figure 2), subcutaneous cellular tissue blocking nerves T12, L1, and ilioinguinal, iliohypogastric, perform Rockey - Davis incision, is dissected by planes to reach cavity without presents data of pain, found it purulent fluid, $10 \mathrm{~cm}$ long vermiform appendix retrocecal, perforated in its middle third (Figure 3), the appendiceal stump was managed by ligation and inversion, proceeded to aspirate abdomen, cul-de-sac, reviewed hemostasis and stitched by planes without drainage, passed to floor of pediatric surgery. It was decided to start a clear liquids diet in the few postoperative hours without distension it was decided to progress the diet on the second day, decided to discharge because of clinical improvement.

*Corresponding author: Moran-Sierra Oscar, Regional Hospital ISSSTE, Av. López Mateos 122, Col. Burócratas Federales, 64380 Monterrey, N.L., Mexico, Tel: +52 818158 9800; E-mail: droscarmoran@gmail.com

Received September 28, 2016; Accepted November 21, 2016; Published November 26, 2016

Citation: Oscar MS, Francisco TB, Benjamin QG, Jose RB, Miguel GR, et al (2016) Appendectomy Realized with Local Anesthesia: A Case Report. Surgery Curr Res 6: 281. doi:10.4172/2161-1076.1000281

Copyright: ( 2016 Oscar MS, et al. This is an open-access article distributed under the terms of the Creative Commons Attribution License, which permits unrestricted use, distribution, and reproduction in any medium, provided the original author and source are credited.Atus ventius cae nostur atis apere 


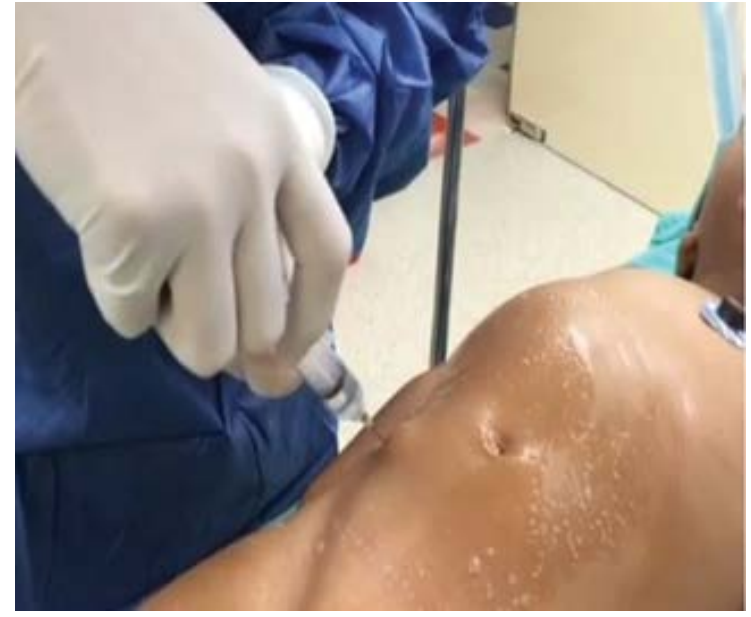

Figure 1: Infiltrating anesthesia in extraperitoneal fasci.

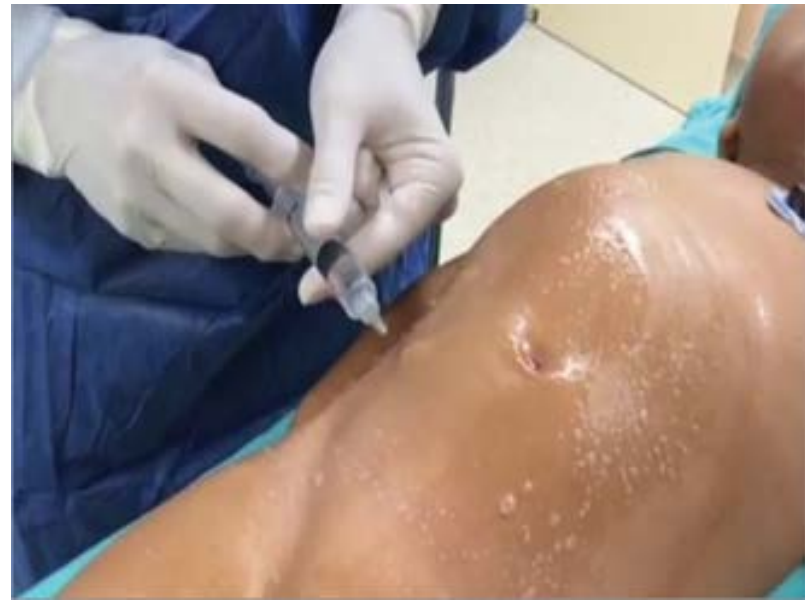

Figure 2: Infiltrating anesthesia in the incision line.

\section{Discussion}

The lifetime risk of developing appendicitis is $8.6 \%$ for males and $6.7 \%$ for females, with the highest incidence in the second and third decades [5]. The establishment of a diagnosis of acute appendicitis has been a problem for many surgeons, even more so in young children than in adults. The inability for them to give an accurate history, diagnostic delays by both parents and physicians, and the frequency of gastrointestinal distress in children are all contributing factors to the misdiagnosis and delay in diagnosis [6].

There is no doubt that the promptly surgical intervention is the elective treatment [3]. The question is: Why should I perform the appendectomy with local anesthesia? The anesthesiologists had handled the peripheral nerves in the members but not in the abdomen because they have had the epidural or either subarachnoid anesthesia [7]. However, sometimes we have older patients with high surgical risk to operate, so have been sought more secure anesthetic techniques [8]. Over the years the techniques of abdominal peripheral block have been refined [9] and for more than forty years, inguinal repair has been performed with local anesthesia, offering less postoperative pain [1012] and this technique has the lowest impact respiratory [13]. In our hospital, we have performed more than 100 appendectomy with local



Figure 3: Appendix perforated.

anesthesia with the same results as we described above, so we decided to report this case. But not everything is perfect because it requires an understanding of the abdominal neuroanatomy, the time to perform the appendectomy is limited, and at the same time not be able to use for visceral analgesia, but becomes available through the use of intravenous sedation and with the gentle handling of tissues [14]. However, these disadvantages create better results than the norm.

\section{Conclusion}

The appendectomy under local anesthesia and sedation is a promising technique that will need further study but may have applications in high risk patients and low resource settings. In general, in case of failure of the epidural anesthesia and as an excellent method of postoperative analgesia can be considered an alternative in high risk patients. Each surgeon, according to his criteria, might use only in special cases to convert it into his technique of choice. Now the surgeons should pay attention on the details, such as the minimum risk, the optimum control of pain, early recovery of the patient. The appendectomy performed with local anesthesia and sedation for the control of visceral pain and anxiety it could be a method with all these expectations.

\section{Ethical Approval}

Written informed consent was obtained from his family. Surgical Procedures were approved by the ethics committee of the School of Medicine-UAS and Hospital. All procedures followed were in accordance with the ethical standards of the responsible committee on human experimentation (institutional and national) and with the Helsinki Declaration of 1975, as revised in 2008.

\section{References}

1. Hutchinson R (1993) Amyand's hernia. J R Soc Med 86: 104-105

2. Fitz RH (1935) Perforating inflammation of the vermiform appendix: with special reference to its early diagnosis and treatment. N Engl J Med 213: 245-248.

3. McBurney C (1889) Experience with early operative interference in cases of disease of the vermiform appendix. Ny Med J 50: 676-684.

4. Loveland JE (1937) Reginald Heber Fitz, the exponent of appendicitis. Yale Biol Med 9: 509 -520.

5. Addiss DG, Shaffer N, Fowler BS, Tauxe RV (1990) The epidemiology of appendicitis and appendectomy in the United States. Am J Epidemiol 132: 910 925. 
Citation: Oscar MS, Francisco TB, Benjamin QG, Jose RB, Miguel GR, et al. (2016) Appendectomy Realized with Local Anesthesia: A Case Report. Surgery Curr Res 6: 281. doi:10.4172/2161-1076.1000281

Page 3 of 3

6. Bundy DG, Byerley JS, Liles EA, Perrin EM, Katznelson J, et al. (2007) Does this child have appendicitis? JAMA 298: 438-451.

7. Davis J (1987) Cirugía general mayor en el paciente ambulatorio. Tratamiento de enfermedades mamarias y hernias de la pared abdominal. Clin Quir Norteam 67: 749-777.

8. Gianetta E, Civalleri D, Serventi A, Floris F, Mariani F, et al. (2004) Anterior tension-free repair under local anesthesia of abdominal wall hernias in continuous ambulatory peritoneal dialysis patients. Hernia 8: 354-357.

9. Malazgirt Z, Dervisoglu A, Polat C, Guneren E, Guven H, et al. (2003) Preperitoneal mesh repair of spigelian hernias under local anesthesia: description and clinical evaluation of a new technique. Hernia 7: 202-205.

10. Amid PK, Shulman AG, Lichtenstein IL (1996) Simultaneous repair of bilatera inguinal hernias under local anesthesia. Ann Surg 223: 249-252.

11. Elton C, Stoodley BJ (2001) Repair of concomitant inguinal and femoral hernias under local anaesthesia. Int J Clin Pract 55: 645-646.

12. Peiper C, Tons C, Schippers E, Busch F, Schumpelick V (1994) Local versus general anesthesia for shouldice repair of the inguinal hernia. World $\mathrm{J}$ Surg 18: $912-915$

13. Murabito R, Vecchio R, Murabito P, Torrisi V, Alongi G, et al. (2005) Developmen of anesthesiological techniques in the surgical treatment of inguinal hernia. Chirurgia italiana 52: 73-77.

14. Shulman AG, Amid PK, Lichtenstein IL (1992) The safety of mesh repair for primary inguinal hernias: results of 3,019 operations from five diverse surgical sources. Am Surgeon 58: 255-257. 